\title{
Identifying Factors Related to the Low Success or Failure of Higher Education Strategic Plans at Arab Universities
}

\author{
Ziad Hunaiti ${ }^{1}$ \\ ${ }^{1}$ Knowledge Well Limited, United Kingdom \\ Correspondence: Ziad Hunaiti, Knowledge Well Limited, United Kingdom. E-mail: Ziad@Knowledgewell.co.uk
}

Received: June 7, 2018 Accepted: September 20, 2018 Online Published: October 29, 2018

doi:10.5539/mas.v12n11p338 URL: https://doi.org/10.5539/mas.v12n11p338

\begin{abstract}
The purpose of this paper is to identify the top 20 factors behind the low success or failure of strategic plans at Arab universities. In addition, the research will be extended to evaluate attitude towards the identified factors. The findings of this research are based on opinions collected from focus group interviews with top- and middle-management at Arab Universities. The research design is based on mixed methods approach in an interpretive paradigm. Hence, the research was conducted using qualitative methodology to achieve the main aim. A 20 factors behind the low success or failure of strategic plans at Arab universities has been presented. This research study has contributed to knowledge by filling the gap in literature though presenting the top 20 the factors behind low success or failure of strategic plans at Arab universities. Moreover, it will be a useful source of information for different stakeholders working in related fields.
\end{abstract}

Keywords: strategic planning, Arab universities, higher education

\section{Introduction}

The Arab World has witnessed a massive expansion in the number of higher education institutions during the last 20 years, many of them representing massive capital investment in oil-producing countries (Hunaiti et al., 2009). However, despite having some of the most ancient and venerable higher education institutions in the world, the presence of Arab universities in world rankings remains very humble considering the number of institutions and the Arab World population. This might be linked with challenges related to strategy planning practices.

\subsection{Strategic Planning in HE}

Higher education institutions can benefit from strategic planning to systematically prepare future development plans to tack all aspects related to higher education resources and practices. This is because strategic planning processes are useful guidelines and approaches for different categories of higher education establishments, who can follow them to select the competitive advantage and unique presence among others within the same higher education arena or globally (Hayward, Ncayiyana \& Johnson, 2003).

The core principle for strategic planning for higher education is to enable continuing amassment process and identification of institutional future goals and required resources in terms of strengths, weaknesses, opportunities and threats (SWOT) in order to have a strong and adjustable plan to face future challenges and to be able to get the most out of the emerging opportunities. This will result in helping the institution to be more effective and sustainable. Hence, strategic planning has been defined as:

'A conscious process by which an institution assesses its current state and the likely future condition of its environment, identifies possible future states for itself, and then develops organised strategies, policies, and procedures for selecting and getting to one or more of them'(Peterson, 1980).

Moreover, strategic planning is a major driving factor in informing and improving the performance and quality of the higher education institution (Masa'deh et al., 2008; Maqableh\&Bany Mohammed, 2015; Mikkawi\& Al-Lozi, 2017). Hence, the main rationale for the planning team is to establish a strategic plan for the institution aiming to achieve the best within the national context, and to be recognised at the international level if possible. In addition, the strategic plan should enable the institution to play a major role in the contribution of satisfying citizens and national needs. Furthermore, strategic planning should enable the evaluation of institution effectiveness and benchmarking with other competitors'(Hayward, Ncayiyana \& Johnson, 2003; Alkandariet al., 
2017; Khalayleh et al., 2017).

In today's competitive and (in the education sector) comparative environment, strategic planning has become more important than ever before, responding to urgent needs and changes in society, particularly in terms of higher education needs, internet, technology, financial support, human resources, global and other aspects related to higher education. Therefore, poor or wrong strategic planning could derail the institution and waste vital resources. This can appear in different forms, including losing high quality members of staff, talented students, accreditation, prestige, ranking, funding and utilisation of important resources. On the other hand, strong planning and implementation process of strategic planning based on the involvement of a wide range of participants from within the institution and from within the community will enable the institution to achieve intended gaols(Wilkinson et al., 2007).

\subsection{Strategic Planning and WUR}

As can be seen from the WUR (Times Higher Education, 2014) for 2013/13 (Table 1), there is a direct link between higher education strategic planning and ranking. The majority of the top 100 research universities consider "international standing" as a main part of their strategic plans (Crook, 2014). Therefore, this research will focus on the factors related to the low success or failure of higher education strategic plans at Arab universities, as these strategic plans have made no significant achievements despite vast investment and planning.

Table 1. Times Higher Education (2014) World University Rankings Criteria

\begin{tabular}{|c|c|}
\hline Indicator & Percentage of overall score \\
\hline Teaching and learning & $30 \%$ \\
\hline Research income generation, size and quality & $30 \%$ \\
\hline Citations & $30 \%$ \\
\hline Income from industry/ innovation & $2.5 \%$ \\
\hline International outlook & $7.5 \%$ \\
\hline Total Score & $100 \%$ \\
\hline
\end{tabular}

\section{Methodology}

As can be seen in Figure, the data collection was conducted in two stages: the first stage was to collect the secondary data presented in the previous chapter; and the second was to collect the primary data presented in the coming chapters. The primary data were collected using research methods as explained in the following sections of this chapter.

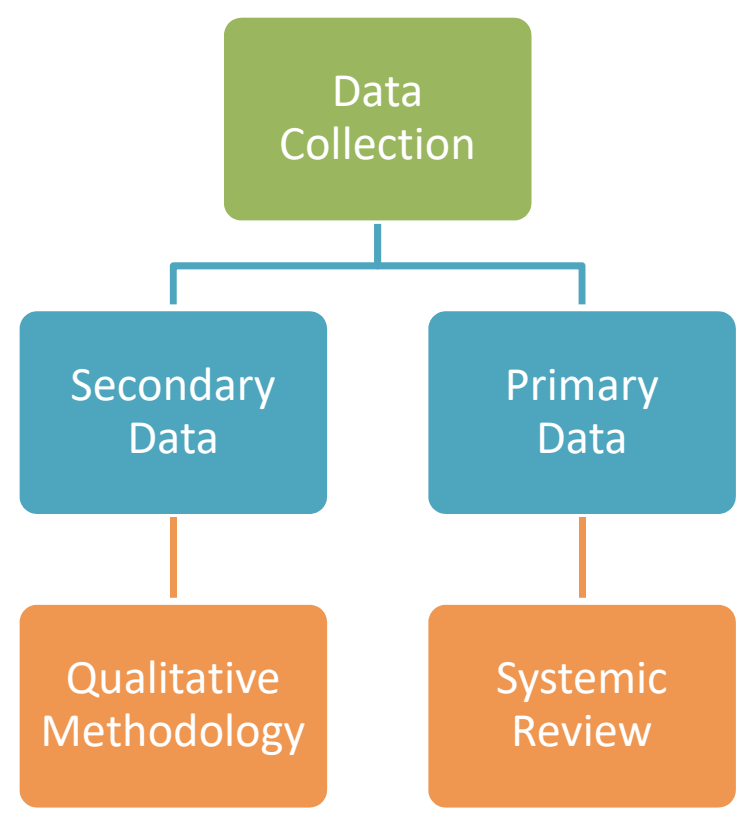

Figure 1. Data Collection 


\subsection{Secondary Data}

In order to achieve this objective, different sources were used to collect enough secondary data related to this project, including, books, journal papers, conference papers, reports, magazine articles, websites, WUR data, and presentations made by higher education officials. In order to evaluate the quality and suitability of secondary data sources, content analysis method was utilized (Neuendorf, 2002). This technique needs pre-identification criteria to enable accomplishing in-depth investigation of the accessible recourses related to the research subject. Figure describes the mechanism of the contents analysis during this study.

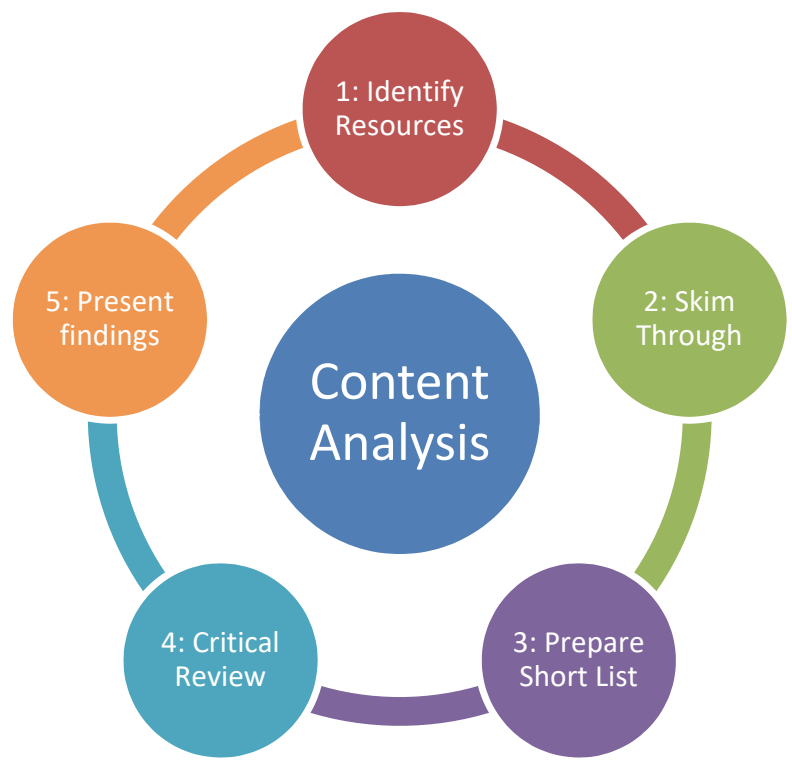

Figure 2. Secondary Data Collection

\subsection{Primary Data}

The research design is based on mixed methods approach (Gall et al., 1996; Driscoll et al., 2007) in an interpretive paradigm (Johnson \& Onwuegbuzie, 2004). Hence, the research was conducted using qualitative methodology to achieve themain aim of the study(Creswell, 2013). Figure 3 illustrates the project research design.

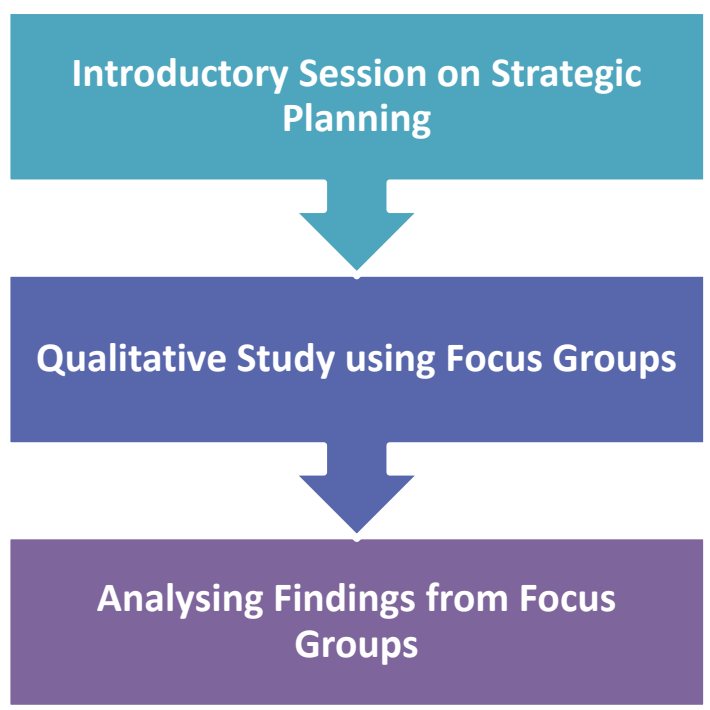

Figure 3. Project Research Design 


\subsubsection{Introductory Session on Strategic Planning}

In order to ensure enough participants from those with an interest in higher education strategic planning, and to provide participants with sufficient background on the topic to enable better engagement, the researcher utilized the opportunity of pre-planned training workshops organized by the Association of Arab Universities on strategic planning (Abu-Orabi, 2014). These workshops were delivered over three days, covering general background and practical skills in accordance with the planning model suggested by the Educational Policy Institute as a practical guide (Wilkinson et al., 2007). The model is presented within five phases divided into sixteen steps. Moreover, the participants were informed about the main aim of the study, their participation was voluntary, and no names were mentioned in the presentation of data. It was also explained to participants that the data might be used in other studies, and that the research outcomes will be published. Moreover, top- and middle-management higher education personnel were targeted to take part in this study based on the fact that top- and middle-management are the main staff members responsible for strategic planning and execution (Wilkinson et al., 2007).

\subsubsection{Qualitative Study Focus Groups}

Focus groups are a qualitative research method that can be used effectively to generate rich information to build a deeper understanding in research projects like this study (Morgan, 1997). In this focus group research, the researcher tries to explore and understand the issues behind poor higher education strategic plans in Arab universities by asking group members to note down "the top 20 factors behind the low success or failure of strategic plans" in their own words, using sticky-notes, which enabled each member to have an equal opportunity to contribute. After that, each member discussed factors with their own group members to come up with one list to be presented along with other lists from other groups. In order to achieve the main objective of this study, the rule-of-thumb was followed in planning focus groups (Kitzinger, 1995).

To ensure the validity of the results, three focus groups were held with six members in each group, to enable better control for the moderator (the researcher). Moreover, the group members were selected to work together on some other activities related to the other training on strategic planning to allow them to be very comfortable to work with each other. In addition, focus groups were conducted in a fully equipped hotel conference room, with tea, coffee and light snacks made available to participants. The time given to each member to provide his or her individual contribution was set to 30 minutes, with 45 for discussion to generate a unified list, based on recommendations for remaining productive during the group duration (Liamputtong, 2011).

Moderator involvement in management of the focus groups was minimized, as recommended in exploratory research. The moderator briefed the research participants on the aim of the group and encouraged them to engage effectively, then they were granted autonomy to discuss the issues they felt pertinent in order to encourage the emergence of relevant data (Liamputtong, 2011). It is worth mentioning that this part of the research could have been conducted by individual interviews rather than focus groups, but that would require more time, more resources and more complex data analysis. Furthermore, it would be difficult to recruit participants with the necessary knowledge and experience for individual interviews, whereas it was easy to recruit focus group members by piggy-backing on the Association of Arab Universities workshops. It was also highly beneficial to allow the experts to discuss among themselves, and this led to the emergency of contextual knowledge that would be difficult to apprehend in individual interviews (Romani 2009).

\subsubsection{Analysing Findings from Focus Groups}

After each group made their own list of the top 20 factors, a panel with one representative from each group took responsibility to convert all lists into one. This was achieved through majority agreement on both the item and the wording. This further stimulated their discussion and enabled refinement of all items without any interference from the researcher during the data analysis, in order to avoid the common shortcoming of such qualitative analysis whereby the researcher becomes too involved in the subject matter (Miles \& Huberman, 1985).

\section{Results}

\subsection{Findings: Part1}

\subsubsection{Arab Universities within the WUR}

Despite the substantial investment in university infrastructure and institutions, higher education output within the Arab World is still below expectations. Arab universities are generally ranked poorly in the WUR.

Arab universities established before 1953 are generally conceptualized as 'old universities' and the later ones as 'modern' ones. The old universities did not appear from analysis of WUR between 2010 to 2014, while the 
modern ones fared little better; only one appeared in three years, two in 2013 and none in 2012 (table 2).

Table 2. Old and Modern University Rankings (Times Higher Education 2014)

\begin{tabular}{cllccc}
\hline Rank by Year & \multicolumn{1}{c}{$2014-2015$} & $2013-2014$ & $2012-2013$ & $2011-2012$ & $2010-2011$ \\
\hline Old & 0 & 0 & 0 & 0 & 0 \\
Modern & 1 & 2 & 0 & 1 & 1 \\
Name(s) & University of & King Abdulaziz & & Alexandria & Alexandria \\
& Marrakech Cadi & University; & & University & University \\
& Ayyad & King Saud & & & \\
& & University & & Egypt & Egypt \\
\hline
\end{tabular}

To get more insight on the Arab universities' appearance in the rankings lists, Figure 4 compares the Arab World, the USA, the UK and Iran (which has been under economic sanctions since 1995) (Katzman, 2010). As can be seen in the figure, the total population of the USA (almost 100 million) is less than that of the Arab World population, has an average annual appearance in the list of 109, while the UK with a quarter of the Arab World population has an average of 49. Lest this be seen as a developing versus developed world issue, Iran performs comparable with the Arab World with a third of its population, and having been in intermittent wars and international sanctions since 1979.

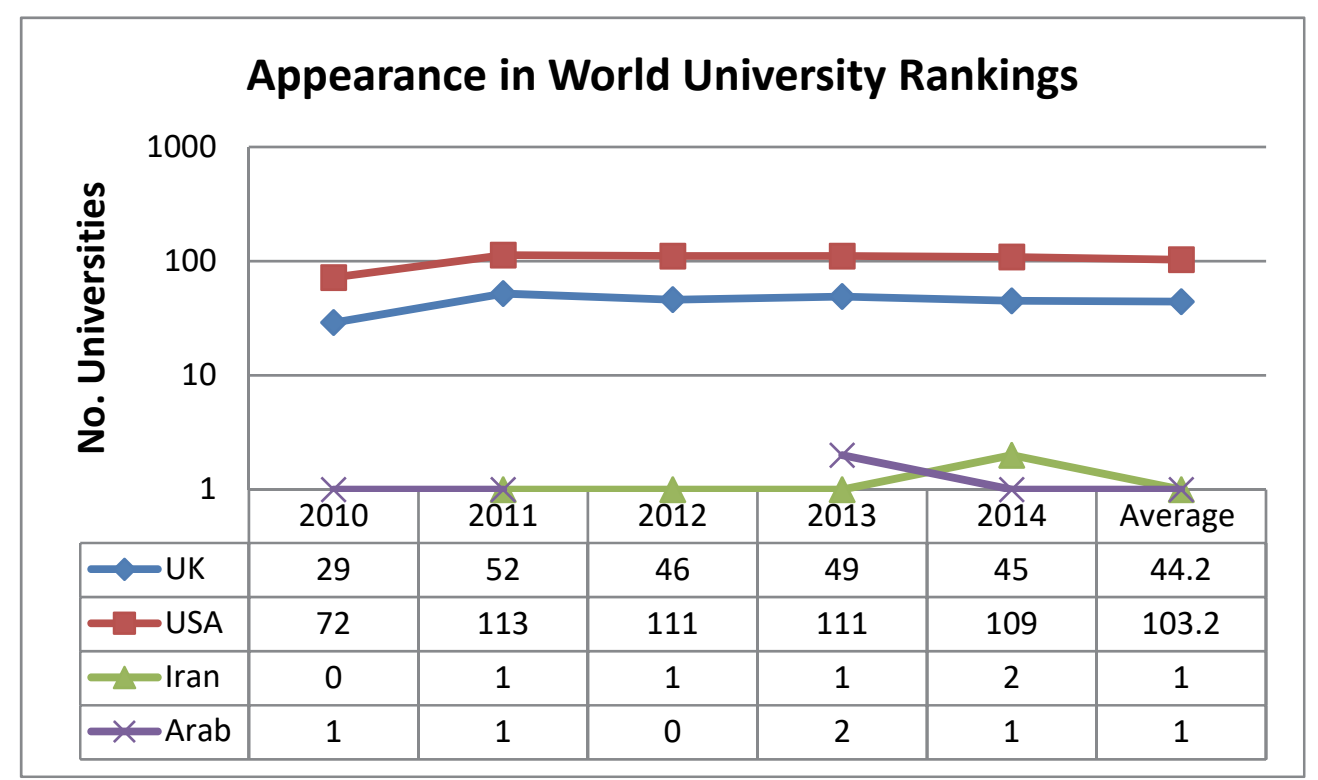

Figure 4. Appearance in World University Rankings

\subsubsection{Analysis of Relevant Studies}

This part of the chapter presents the review obtained from selected publications related to Arab universities and their presence in the WUR. It should be noted that one of the main challenges facing this project was to find peer reviewed publications directly related to the subject; hence other publications with a broader focus were used.

\section{A. Are University Rankings Relevant to the Arab World?}

This article was written by student at Al Azhar University in Egypt (McPhedran, 2013a), with the primary aim of investigating why Al Azhar University, which is one of the oldest educational institutions in the world, has not been ranked as high as some Saudi universities established in the last few years. McPhedran (2013a) claims that the reason Saudi universities achieved high ranking was due to some partnerships with other highly ranked Western universities, which resulted in sharing publications citations, allowing them to score well in the International Outlook elements part of the Time Higher Education ranking criteria. In addition, he believes that partnership might have helped Saudi universities in future research collaboration and enhancement of research 
output quality, and the demise of such partnerships would result in plummeting rankings in future results. Furthermore, the author observes that the Saudi achievements have been confined to the areas of science and technology, where massive capital investment can produce more immediate results, with poor performance in arts, humanities and social science.

Furthermore, the author sees the language of publications as a major obstacle, since the ranking was based on publications written in English, which means many of the Arab universities who publish in Arabic could not use the majority of their publications for the ranking assessment. Ironically, universities with a firm grounding in Arabic publishing and more mature research and publication generally in Arabic, one of the major world languages (particularly universities in Egypt and Syria), along with Francophone universities in North Africa, will be outperformed in terms of publications by nouveau universities in Saudi Arabia and elsewhere in the GCC, where universities outsource such activities to international academicians publishing in English; for instance, Qatar imported its university system wholesale from the US (Siegel, 2013).

B. New Rankings Show Problems, Promise, in Arab Higher Education

This article published in September 2014 highlights Arab universities' appearance in the QS World University Rankings for year 2014 (Faek, 2014). In that year there was some increasing strength demonstrated by the inclusion of 29 Arab universities, in comparison with only 10 the previous year. Moreover, it showed that Saudi Arabia was leading with four universities, followed by the UAE with three, which means some changes are happening; from colonial times until the 2000s, the traditional locales of modern learning achievement were Egyptian and Lebanese universities.

Faek (2014) attributed the rapid insurgence of Gulf universities in the QS ranking to high capital investment (from oil revenues) in higher education and scientific research, the use of foreign consultants, and the King Abdullah Scholarship Program started in 2015, aiming to send over 150,000 Saudi students to study abroad (mainly the USA) and the impact of this program on building new Saudi colleges and its contribution in research output.

Despite this rapid progress, Faek (2014) emphasized that higher education in the Gulf region still faces some challenges, in particular limited library resources for research at a postgraduate level. In addition, the author noted that Arab universities' progress is still very limited to be compared with other universities in the world. The only three Arab universities mentioned in internationally peer-reviewed publications were King Fahad University of Petroleum and Minerals, the American University of Beirut and the United Arab Emirates University, the second of which is from the old guard Arab institutions.

\section{How Saudi Universities Rose in the Global Rankings}

This article was published in reflection to the appearance of King Saud University in the 2013 QS rankings (McPhedran, 2013b). In tandem with the contemporaneous article (McPhedran, 2013a), this paper confirms that this sudden achievement is due to partnership between of King Saud University and Western universities, particularly freeriding the credit of joint publications. While King Saud University claims to have improved their research output in the areas of science and mathematics education in Saudi Arabia, the author notes that:

"After all, this argument goes, none of the Saudi schools made the top 100 in the big three rankings this year. If they want to climb further up the rankings ladder, the Saudi universities will need more radical reforms that will increase freedoms across all fields".

D. Towards Building World Class Universities in the Arab World

This paper observed that colleges and universities across the Arab World show more interest in different world university ranking systems than before, and some of them started reform agendas to improve their ranking (Al-Kabi, 2014). In addition, this paper calls for new effective strategic plans to help Arab universities to become capable to compete in global rankings. Moreover, the paper identified the following reasons why Arab universities are still lagging behind in the listings:

- Governance and strategic leadership: mainly lack of institutional autonomy in the Arab World and academic freedom.

- Teaching and learning:Arab universities are still using old fashion teaching and learning methods depending on rote learning, which do not help in building research skills. In addition, student assessment is still based on written examinations, which limits the opportunity of life-long learning.

- High-quality and quantity research: the quality and quantity of research work produced by researchers in the Arab World is still below international standards and is mainly conducted for the purpose of 
career promotion. Moreover, research in Arab universities lacks financial and commercializing support. Moreover, most university top management do not prioritise research, thus many good quality researchers left the Arab World to work overseas (the brain drain effect common among developing countries).

- Quality assurance and accreditation:the vast majority ofquality assurance committees and centres in Arab universities are narrowly focused on observance of their rules instead of helping in the improvement of institutional teaching and learning quality and overall performance. In addition, some accreditation commissions' rules conflict with those of higher education ministries.

The main outcomes from the conducted critical review on the past work are: firstly, there is lack of studies performed on the research topic in general and recent studies in particular (after the Arab Spring). Secondly, there are some magazine articles discussing the situation of Arab universities within the WUR, but they do not provide analytical results and they represent writers' own points of view, therefore to generate sufficient secondary data a systemic review was conducted to identify and compare the position of Arab universities within the WUR. Thirdly, there is lack of studies establishing links between strategic planning and achievements within the WUR. Lastly, there is lack in studies that involve participants from a wider sample of Arab countries. Hence, these outcomes support the justification for the initiation of this research work, and will be useful for filling the gap in literature with recommendations for future research.

\section{a. Findings: Part 2}

Participants in the groups were recruited from eight Arab countries, namely Jordan, Bahrain, Egypt, Sudan, Palestine, Libya, Lebanon and Iraq. These Arab countries collectively have a population of around 180 million. In view of this, the sample of education experts is considered to be a very good representative statistical sample of higher education systems in the Arab World as a whole on a national basis. Moreover, the participants comprised a good mixture of top and middle educational managers and planners, including university presidents, vice presidents and deans, who are likely to be involved in the process of leading and executing strategic plans.

5 shows the final, agreed upon list compiled from the three different focus group lists after the discussion.

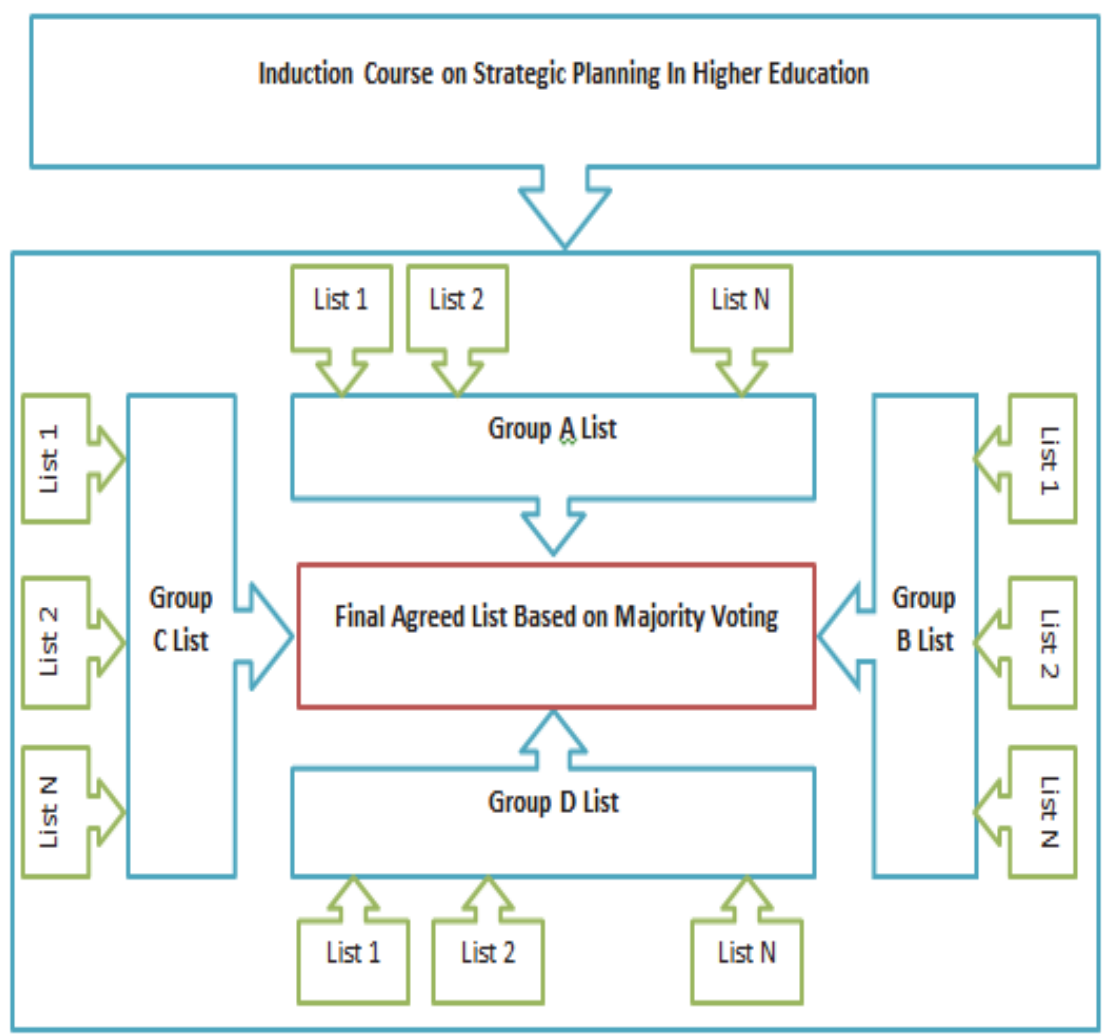

Figure 5. Focus Group Activities 
Table 3. The Top 20 Factors Related to the Low Success or Failure of Strategic Plans

\begin{tabular}{cl}
\hline No. & \\
\hline 1 & Not hiring enough expertise in strategic planning. \\
2 & Political instability in the region. \\
4 & Other Arab institutions using similar strategic plans. \\
5 & Adopting Western strategic plans not suited to Arab countries. \\
& Lack of available data from inside and outside the educational institutions for strategic planning \\
6 & Poor communication and follow-up by the higher education authorities. \\
7 & Numerous universities competing with the same products in the same country. \\
8 & The use of non-deliberate planning mechanisms. \\
9 & Lack of staff experience in managing and implementing strategic plans. \\
10 & Lack of necessary resources for capacity building. \\
11 & Focusing on the local or regional level, without regard to the international level. \\
12 & Having poor research outcomes related to strategic planning. \\
13 & Rapid and uncoordinated changes in higher education policies. \\
15 & Lack of autonomy in educational institutions. \\
16 & Social and cultural challenges. \\
& Focus on income generation from tuition fees as main source of income, while unknowing or \\
17 & ignorant of other sources. \\
18 & Issues related to the mechanism of selecting top management in higher education institutions. \\
& Lack of involving members from across the institution in the strategic planning committees (not \\
19 & $\begin{array}{l}\text { achieving ownership) and lack of appreciation of members of the planning committees. } \\
\text { organizations. }\end{array}$ \\
& Factors associated with universities' student admissions/acceptance system.
\end{tabular}

\section{Discussion}

Nowadays, higher education systems require adopting forward-looking management practices that effectively respond to the needs and challenges of the twenty-first century. Recently, much research work has been focused on identifying these challenges. Since higher education is a multidimensional and complex system, it is not possible to arrive at one set of quality factors applicable to all countries. The identification and formulation of the above twenty factors was based on the individual groups' discussion and the common final debate of the three lists. In this section, each of the above factors is thoroughly discussed.

\subsection{Not Hiring Enough Expertise in Strategic Planning}

It is well known that higher education top leadership is responsible for ensuring the effective management of the institution and for planning its future development. One of the main responsibilities of top management is the development and approval of institutional strategic plans. It was concluded from the discussion that some Arab universities do not have sufficient resources for strategic planning, or sometimes they consider it to be a routine managerial task, thus they allocate the whole responsibility for strategic planning to some members of management with limited experience. This practice has resulted in poor strategic planning and allocation of responsibility for real implementation to the wrong or inexperienced people in the management section (Wilkinson et al., 2007).

\subsection{Political Instability in the Region}

The relationship between higher education and political instability is diverse and complex. Local and regional instabilities have a pronounced impact on the quality, development and content of education. Political 
instabilities and conflicts affect governmental investment in education as well as educational strategies. Besides, civil wars and conflicts adversely affect the quality and operation of institutions. It is clear that the Arab region has been in the midst of numerous unstable political situations, which inhibit suitable strategic plans able to cope with many changes. Furthermore, Arab countries with political instability find it hard to cope with the influx of refugee from affected countries. The quality of education consequently suffers due to a lack of qualified teachers as well as shortages in basic educational needs to serve massive and fluctuating populations (Al-Rashdan, 2009).

\subsection{Other Arab Institutions Using Similar Strategic Plans}

In some cases the lack of competition between institutions of higher education in the same country and the region resulted in the implementation of similar strategic plans. Consequently, this might result in common negativities, like offering the same products, falling into the same mistakes, limiting institutional innovation, wasting resources and missing opportunities (Lamine, 2010).

\subsection{Adopting Western Strategic Plans not Suited to Arab Countries}

Some of the universities within the Arab region are inspired by other western universities and try to clone their achievements by following or adopting same strategic plan, without taking into consideration the two different environments. This has resulted in facing many challenges during the implantation phases of the plan (Lamine, 2010).

\subsection{The Use of Non-Deliberate Planning Mechanisms}

The lack of knowledge and awareness of the importance of strategic planning might lead some higher education planners to follow non-effective planning methods, resulting in the production of poor or unrealistic strategic plans, leading to wasting time and resources without achieving institutional goals (Wilkinson et al., 2007).

\subsection{Lack of Staff Experience in Managing and Implementing Strategic Plans}

Academic institutions are worthless if they do not have the right staff with the right experience. Unqualified managers mean poor implementation of strategic plans. In some cases most attention is given to the planning stage of the strategic plan, which could result in very good abstract plans, but the lack of an appropriately skilled and experienced strategic leader to take responsibility for driving the implementation, delegating to the right members of staff to implement each stage of the plan according to their specialty, and conducting the necessary review to perform any necessary alignment prevents effective implementation (Lamine, 2010).

\subsection{Focus on Income Generation from Tuition Fees as Main Source of Income, with Ignorance of other Sources}

Many higher education institutions in Arab World, in particular private ones, still depend on fees collected from students as their main major source of income, which makes it hard to cover costs and invest in development plans. This is more of a challenge in poor (i.e. non-GCC) countries (Lamine, 2010).

\subsection{Issues Related to the Mechanism of Selecting Top Management in Higher Education Institutions}

The higher education management selection process in the majority of Arab countries is still not at the same level of leading higher education institutions around the world, and old management styles are the default position. Some universities still consider years of experience to be the main criterion of management expertise, rather than academic and research achievements, with minimal consideration for managerial achievements. In most cases the (mainly ceremonial) president of the university can be recruited from outside the institution, but the other members of management have to be from within the institution, which limits the abilities of the president to attract experienced leaders and perform real strategic reform. Moreover, in some countries higher education management appointments are influenced by political, social and geographical situations, which in turn affect developments (Lamine, 2010).

4.9 Lack of Involving Members from across the Institution in the Strategic Planning Committees (not AchievingOwnership) and Lack of Appreciation of Members of the Planning Committees

The vast majority of Arab universities depend on a few individuals to prepare institutional strategic plans, with very few reaching out to wider participation and contribution from members of the same institution, the local community and other bodies (Wilkinson et al., 2007; Adewale \& Esther, 2012).

\subsection{Poor Collaboration and Communication between Academic Institutions and Local CommunityOrganizations}

The level of collaboration between different universities within the same county or within the region is still very limited, and does not even exist in some countries. Moreover, Arab universities do not have strong engagement with the local community, industry and professional organizations(Wilkinson et al., 2007; Al-Rashdan, 2009). 


\subsection{Factors Associated with Universities'Student Admissions/Acceptance System}

Most universities in the Arab World depend on a national, centralized admission system, which allocates students seats and study programs based on achievements in high school certification. This compels students to accept study programs far from their personal interest in order to have the chance to go to a state university. Moreover, some universities will have better chance to get high achievers than others, in particular those located in the capital and major cities (Lamine, 2010).

\subsection{Lack of Available Data from Inside and Outside the Educational Institutions for Strategic Planning Use}

In order to produce a very strong strategic plan, different data and statistical information is required from certain agencies (e.g. the expected number of high school students converting to higher education in four years' time); such information is needed to consider future share by each institution and link that with development plans. In a number of Arab countries, such information is not available, is inaccurate, or it cannot be shared between different agencies. Therefore, this could result in the development of poor strategic plans which do not take into account the emerging threats or opportunities (Wilkinson et al., 2007).

\subsection{Poor Communication and Follow-up by the Higher Education Authorities}

The vast majority of Arab countries create national strategic plans for higher education under a central authority, to be used as reference for higher education institutions. In some cases these plans are made without (or with minimal) involvement of the wider spectrum of stakeholders. In addition, national strategy might not be communicate clearly to higher education institutions, which results in the production of institutional strategic plans that do not conform to the national agenda, or might clash with it. This in turn will have an impact on achieving national and institutional strategic goals (Wilkinson et al., 2007).

\subsection{Numerous Universities Competing with the Same Products in the Same Country}

Within the Arab World, it is easy to find universities offering the same study programs within a very limited number of subjects within the same geographical area. This is related to a number of issues, such as newly established universities copying other universities' programs, compulsion from central authorities to satisfy social or political pressure from certain geographical areas and a lack of data or collaboration from/with related agency to modernise programs according to market needs. Universities often focus on quick profits by following the current fashion rather than trying to specialise in key areas and offering study programs to satisfy future needs (Al-Rashdan, 2009; Lamine, 2010).

\subsection{Lack of Necessary Resources for Capacity Building}

In many cases, higher education institutions are required to in invest in capacity building to train staff in planning, managing and implementing strategic plans. In Arab countries, this sometimes does not happen due to a lack of awareness of the importance of strategic planning and considering this to be a bureaucratic management task, and limited institutional budgets. This directly affects the development of strategic plans' quality and results in poor outcomes in implementation (Wilkinson et al., 2007; Ahmed \& Siddiek, 2012).

\subsection{Focusing on the Local or Regional Level, without Regard to the International Level}

Very few universities within the Arab World are truly working towards becoming regional or international universities, as reflected in the low level of international collaboration, consequently, losing the opportunity to recruit talented students from the international market, besides being unable to attract world-class academicians, losing funding opportunities, and lagging behind the world in terms of the latest innovations in higher education. Hence, focusing on the local level only results in producing strategic plans that do not take into consideration the external opportunities and threats (Al-Rashdan, 2009).

\subsection{Lack of Autonomy in Educational Institutions}

Most academic institutions are centrally linked with the ministries of education, and the degree of autonomy given to institutions is generally low, although this varies according to national educational regulations and policies. Limited autonomy is a disincentive for institutions to make effort on strategy and implementing serious goals (Al-Rashdan, 2009).

\subsection{Having Poor Research Outcomes Related to Strategic Planning}

As with many other areas, the research output from most Arab universities does not tackle social, economic, technological and other issues in the Arab region. Research output related to strategic planning is very limited. This can be seen as a shortcoming, since there is not enough information in the public domain that can be used by strategic planners to benefit from, by replicating success or avoiding making the same mistakes. As a result, 
strategic planners might need to learn from experiences that result in negative outcomes or come at the cost of time and resources (Al-Rashdan, 2009; Ahmed \& Siddiek, 2012).

\subsection{Rapid and Uncoordinated Changes in Higher Education Policies}

Most of the countries within the Arab region suffer many government reshuffles during very short periods. Moreover, it is the norm that every new government is likely to discard previous government agendas and strategic plans, to come up with new ones. Hence, compounding the problems of their lack of autonomy, higher education institutions are intermittently forced to change their strategic plans in order to accommodate their goals within the new polices and national agenda. As a result, this makes it impractical and indeed inefficient for higher education institutions to invest serious time, effort and money in strategic planning and implementation (Al-Rashdan, 2009; Lamine, 2010).

\subsection{Social and Cultural Challenges}

Most aspects of higher education in the Arab World are colored by socio-cultural factors, which may include tribal modes of decision making and working patterns. As a result, in several situations higher education institutions have been established to satisfy immediate community needs rather than a strategic approach, which results in expanding the number of higher education institutions with limited budgets. Moreover, that has contributed to limit the mobility of students and skilled academic staff, bureaucratically confining them to certain regions. In addition, higher education institutions have been forced to employ a high number of extra staff above requirements in order to please local communities (e.g. national employment quotas in many countries). This wider context overshadows all strategic planning and fossilizes institutional practices (Wilkinson et al., 2007; Al-Rashdan, 2009; Lamine, 2010).

\section{References}

Abu-Orabi, S. (2014). Scientific research and higher education in the Arab world. University of Barcelona. $\begin{array}{llll}\text { Retrieved } \quad \text { March, 13, 2015, from } & \text { 13, }\end{array}$ http://www.ub.edu/LinkingMedGulf/docs/kickoff_meeting/scientific_research.pdf

Adewale, A. R., \& Esther, M. M. (2012). The relationship between stakeholders' involvement in strategic planning and organisation's performance: A study of the University of Venda. International Business \& Economics Research Journal, 11(11), 1175-1190.

Ahmed, M. A. H., \& Siddiek, A. G. (2012). Strategic quality management in the Arab higher education institutes: A descriptive and analytical study. International Journal of Business and Social Science, 3(24), 90-103.

Albaum, G. (1997). The Likert scale revisited. Journal of the Market Research Society, 39, 331-348.

Al-Kabi, M. N. (2014). Towards building world classuniversities in the Arab world.The 4th International Arab Conference on Quality Assurance in Higher Education (IACQA'2014), April 1-3, 2014, Zarqa University, Zarqa, Jordan, 995-999.

Alkandari, A., Masa'deh, R., \& Al-Lozi, M. (2017). Knowledge management and its role on organizational crisis management: A literature review. Journal of Social Sciences (COES\&RJ-JSS), 6(4), 833-850.

Al-Rashdan, A. (2009). Higher education in the Arab world: Hopes and challenges. Arab Insight, $26,77-90$.

Ayyubi, N. (2015). Arab bureaucracies: Expanding size, changing roles. In G. Luciani (Ed.) The Arab State, 129-150. $2^{\text {nd }}$ edition. New York: Routledge.

Babbie, E. R., Halley, F. S., Wagner, W. E., \& Zaino, J. S. (2007). Adventures in social research: Data analysis using IBM SPSS statistics. Thousand Oaks, Cal.: Sage Publications, Inc.

Clarke, K. R., \& Warwick, R. M. (2001). Change in marine communities: An approach to statistical analysis and interpretation (2nd ed). Plymouth, UK: Primer-E Ltd.

Creswell, J. W. (2013). Research design: Qualitative, quantitative, and mixed methods approaches. London: Sage Publications.

Crook, R. (2014). The 100 most international universities in the world 2014.Times Higher Education. Retrieved March

3 ,

2015 , fromhttp://www.timeshighereducation.co.uk/news/the-100-most-international-universities-in-the-world-2 014/2010783.article

De Levie, R. (2004). Advanced excel for scientific data analysis. Oxford: Oxford University Press. 
Driscoll, D. L., Appiah-Yeboah, A., Salib, P., \& Rupert, D. J. (2007). Merging qualitative and quantitative data in mixed methods research: How to and why not. Ecological and Environmental Anthropology, 3(1), 18-28.

Faek, R. (2014, 22 September). New rankings show problems, promise, in Arab higher education. Al-Fanar Media. Retrieved January10,

2016 , fromhttp://www.al-fanarmedia.org/2014/09/new-rankings-show-problems-promise-arab-higher-education-2

Gall, M. D., Borg, W. R., \& Gall, J. P. (1996). Educational research: An introduction. London: Longman Publishing.

Hayward, F. M., Ncayiyana, D. J., \& Johnson, J. E. (2003). A guide to strategic planning for African higher education institutions. Cape Town: Centre for Higher Education Training.

Hinton, K. E. (2012). A practical guide to strategic planning in higher education. Ann Arbor, MI: Society for College and University Planning.

Hunaiti, Z., Mansour, M., \& Al-Nawafleh, A. (2009). Electronic commerce adoption barriers in small and medium-sized enterprises (SMEs) in developing countries: The case of Libya. IBIMA Business Review, 2(5), 37-45.

Johnson, R. B., \& Onwuegbuzie, A. J. (2004). Mixed methods research: A research paradigm whose time has come. Educational Researcher, 33(7), 14-26.

Katzman, K. (2010). Iran sanctions. Collingdale, PA: DIANE Publishing.

Khalayleh, W., Masa'deh, R., \& Al-Lozi, M. (2017). Administrative empowerment and its role on the work teams Performance: A literature review. Journal of Social Sciences (COES\&RJ-JSS), 6(4), 851-868.

Kitzinger, J. (1995). Qualitative research: Introducing focus groups. BMJ (Clinical Research Edition), 311(7000), 299-302.

Lamine, B. (2010). Towards an Arab higher education space: International challenges and societal responsibilities. Proceedings of the Arab Regional Conference on Higher Education. Paris: UNESCO.

Liamputtong, P. (2011). Focus group methodology: Principle and practice. Thousand Oaks, Cal.: Sage.

Maqableh, M., \& Bany Mohammed, A. (2015). The acceptance and use of computer based assessment in higher education. Journal of Software Engineering and Applications, 8(10), 557.

Masa'deh, R., Hunaiti, Z., \& Bani Yaseen, A. (2008). An integrative model linking IT-business strategic alignment and firm performance: The mediating role of pursuing innovation and knowledge management strategies. Communications of the International Business Information Management Association (IBIMA) Journal, 180-187.

McPhedran, C. (2013a, 15 October). Are university rankings relevant to the Arab world? Al-Fanar Media. $\begin{array}{llll}\text { Retrieved January } & 10, & 2016, & \text { from }\end{array}$ http:/www.al-fanarmedia.org/2013/10/are-university-rankings-relevant-to-the-arab-world/

McPhedran, C. (2013b, 15 October). How Saudi universities rose in the global rankings. Al-Fanar Media. $\begin{array}{lll}\text { Retrieved January } & \text { 2016, }\end{array}$ fromhttp:/www.al-fanarmedia.org/2013/10/how-saudi-universities-rose-in-the-global-rankings/

Mikkawi, B., \& Al-Lozi, M. (2017). The impact of knowledge management infrastructure on academic staff effectiveness: An empirical study at The University of Jordan. Jordan Journal of Business Administration, 13(1), 95-127.

Miles, M. B., \& Huberman, A. M. (1985). Qualitative data analysis. Newbury Park, Cal.: Sage.

Morgan, D. L. (1997).Focus groups as qualitative research. Thousand Oaks, Cal.: Sage Publications.

Norušis, M. J. (1994). SPSS professional statistics 6.1. New York: Prentice Hall.

O'Brien, R. (1998). An overview of the methodological approach of action research. University of Toronto: Faculty of Information Studies.

Peterson, M. W. (1980). Analyzing alternative approaches to planning. In P. Jedamus \& M. Peterson (Eds.), Improving Academic Management: Handbook for Planning and Institutional Research (pp. 140-141). San Francisco: Jossey-Bass.

Ramady, M. A. (2010). The Saudi Arabian economy: Policies, achievements, and challenges. Heidelberg: Springer Science \& Business Media. 
Ribbins, P. (2007). Interviews in educational research: Conversations with a purpose. Research Methods in Educational Leadership and Management, 2, 207-223.

Romani, V. (2009). The politics of higher education in the Middle East: Problems and prospects. Middle East Brief, $36,1-8$.

Siegel, R. (2013). Instead of sending students abroad, Qatar imports U.S. colleges [online]. National Public Radio. January 18 , 2016 , fromhttp://www.npr.org/sections/parallels/2013/12/24/256874173/instead-of-sending-students-abroad-qatar -imports-u-s-colleges

Sudman, S., \& Bradburn, N. M. (1982). Asking questions: A practical guide to questionnaire design. San Francisco: Jossey Bass.

The Arab-Swiss Chamber of Commerce and Industry (2009). The Arab world. [online]. Retrieved March 13, 2015, from http://www.casci.ch

Times Higher Education (2014, December 18). Times higher education world university rankings. Retrieved March 13, 2015, fromhttps://www.timeshighereducation.com/world-university-rankings

Tromp, S. A., \& Ruben, B. D. (2010). Strategic planning in higher education: A guide for leaders. New Brunswick, NJ: Rutgers University, Center for Organizational Development and Leadership.

UNESCO (2012). World Arabic language day. Retrieved March 13, 2015, from http://www.unesco.org/new/en/unesco/events/prizes-and-celebrations/celebrations/international-days/world -arabic-language-day/

Wilkinson, R., Taylor, J. S., Peterson, A., \& Machado-Taylor, M. D. L. (2007). The practical guide to strategic enrolment management. Virginia Beach, VA: Educational Policy Institute (EPI).

\section{Copyrights}

Copyright for this article is retained by the author(s), with first publication rights granted to the journal.

This is an open-access article distributed under the terms and conditions of the Creative Commons Attribution license (http://creativecommons.org/licenses/by/4.0/). 